\title{
ORTADOĞU'DA ARAP SOSYALİZMI VE MIŞEL EFLAK
}

\section{Arab Socialism at Middle East and Michel Aflaq}

\author{
Abil GÜNDOĞDU ${ }^{1 *}$ iD \\ ${ }^{1}$ Kastamonu Üniversitesi, Sosyal Bilimler Enstitüsü, Uluslararası İlişkiler Anabilim Dalı, Kastamonu, Türkiye.
}

\section{Ö Z}

Fransız Devrimi'nin etkilediği toplumlar ulus, ulusçuluk, ulusun egemenliği, demokrasi, sekülerizm, adalet gibi kavramları içine alan ulus devlet inşa etme ereğiyle Orta Çağ döneminin yönetim sistemi olan imparatorluklara ve temsil ettiği değerlere karşı başkaldırmışlardır. Orta Doğu'da da 19. yüzyıldan itibaren Osmanlı İmparatorluğu'na karşı Arap ayaklanmaları başlamıştır. Bu ayaklanmalar bağımsızlık karakterli olsa da amaç ve kullanılan araçlar bakımından batıda ki örneklerinden farklı öğeler içerdiği görülmektedir. Batıda ki isyanlar ve bağımsızlık hareketlerinde seküler ulusçuluk ve ulusal egemenlik kavramları öne çıkarken Arap isyanları ve bağımsızlık hareketlerinde dini öğeler üzerine inşa edilmiş milliyetçilik ve hanedan yönetimler öne çıkmıştır. 1 Dünya Savaşı sonrası Orta Doğu Arap coğrafyasında Irak, Suriye ve Mısır'da İngiliz ve Fransız mandası altında monarşiyle yönetilen devletler kurulmuştur. Oluşan manda yönetimlerine karşı 20. yüzyılın ilk çeyreğinden itibaren Batıda eğitim almış Araplar tarafindan Avrupa'da ki ulus devlet örneğini rol model alarak Arap Rönesans'ını gerçekleştirmek ereğiyle siyasi harek etler başlamışır. Bu siyasi hareketlerin en öne çıkanı ise toplumsal ve politik etkisiyle Arap sosyalizmidir. Arap sosyalizminin kurucu babası olarak tanınan Fransız Devrimi'nin getirdiği kavramlarla Fransa'da Sorbonne Üniversitesi'nde tanışan Arap aydını, ideolog ve 1lımlı bir sosyalist olan Mişel Eflak Orta Doğu'da fikirleri ile günümüze kadar devam eden önemli etkileri olmuştur. Eflak Arap halklarının yüzyıllardır içinde bulunduğuna inandığı Orta Çağ karanlı̆̆ından kurtarmak istemiş̧tir. Ortaya koyduğu fikirler Arap coğrafyasında karşılık bulmuş ve Baas adı verilen yönetimler olarak iktidara gelmiştir. Bu iktidarlar bir araya gelip Arapları birleşik bir devlet altında toplama denemelerine rağmen uygulamalarda siyasi ve sosyolojik bir başarı sağlayamamıştır.

Anahtar Kelimeler: Ulusalcı Arap Sosyalizmi, Baas Partisi, Mişel Eflak, Pan-Arapçılık, Ortadoğu.

\begin{abstract}
A B S T R A C T
The nations effected by French Revolution revolted againts medieval heritage empires and the values to get individual rights and freedoms and built nation state which contained nation, nationalism, nation sovereignty, secularism, democracy and justice. Also, in the Middle East, Arabic nations had rebelled against Ottoman Empire partically by the effect of French Revolution with the wish of establlisment of their own states since the 19th century. While secular nationalism and national sovereignty came to the fore in the uprisings and independence movements in the West, nationalism and dynasty governments built on religious elements came to the fore in the Arab revolts and independence movements. As a result of this situation, states that were governed by the monarchy under the mandate of British and French in Iraq, Syria and Egypt in the Middle East Arab geography after the First World War. Political movements have started with the aim of realizing the Arab Renaissance by taking the model in Europe as a role model from the first quarter of the 20th century against the mandate administrations. The most prominent of these political movements is Arab socialism with its social and political influence. After the quarter of 20 th centurty Michel Aflaq who on Arabic intellectual having western education, ideologist and a modest socialist wanted to save Arabic nations from the darkness of medieval by means of synthesizing his western origin revolutionary thoughts whit local values. Althought the nationalists and socialist ideas that the former had a place or met in Arab World and came to fower, also trials of combinig all the Arabs in united states, he couldn't get or achieve a political or sociological success in applications or practices.
\end{abstract}

Keywords: Nationalist, Arab Socialism, Baas Party, Michel Aflaq, Pan-Arab, Middle East.

Please cite this paper as follows/Atıf için:

Gündoğdu, A. (2020). Ortadoğu'da Arap Sosyalizmi ve Mişel Eflak. Alınteri Sosyal Bilimler Dergisi, 4 (1): $13-26$.

\footnotetext{
* Sorumlu yazar/Corresponding author

E-mail: abilgundogdu14@gmail.com (A. Gündoğdu)
} 


\section{GİRIŞ}

Avrupa'da Orta Çağ döneminde düşünsel, yönetimsel ve toplumsal alanda skolastik düşüncenin hâkimiyeti yaşanmıştır. Derebeylikler, krallıklar ve Kilise toplumlara tek ve en yüce sadakat odağı olarak Tanrı'yı işaret etmişler ve onun adına toplumları yönetmişlerdir (Oran, 2015: s.4). Sosyolojik açıdan Ortaçağ Avrupa'sı dini ve siyasi yönetici sınıf ile halk arasında kaynak paylaşımındaki adaletsizliğin ortaya çıkarttığı sosyal buhranların yüksek olduğu bir dönem olarak karşımıza çıkmaktadır. Ortaçağ Hukuku ise krallar ve din adamları tarafından Tanrı adına inşa edildiği iddiasıyla şekillendirilmiş, dolayısıyla dönemin hukuk organları sorgulanamaz bir kimliğe bürünmüştür. Uygulanan hukukun dogmatik düşünce sistemine karşı rasyonel sorgulama veya eleştiri yapanlar kişi ya da gruplar Papalık otoritesini tehdit ediyorsa Papalığın emrindeki engizisyon mahkemelerinde, krallıkların veya derebeyliklerin otoritesini tehdit ediyorsa emirlerindeki mahkemelerce yargılanmış ve sisteme ne derece tehditse o oranda cezalandırılmıştır (Helden, 1995; http://galileo.rice.edu/). Ekonomik açıdan özellikle Avrupa'nın Doğuyla olan ticaret yollarının Müslümanların kontrolüne geçmesiyle ekonomik bir daralma ve kriz yaşatmıştır. Ayrıca Osmanlı Devleti'nin sınırlarının Avrupa'ya doğru ilerlemesi coğrafi ve siyasi baskı yaratmıştır. Ortaçağ'ın ekonomik siyasi ve sosyal durumu sonraki dönemlerde Avrupa'nın karanlık çağı olarak adlandırılmıştır (Durgun, 2014: ss.283-304). Avrupa bu durumu aşmak için yeni coğrafyalar yeni kaynaklar ve yeni ticaret yolları bulma çabasına girmiştir. Bu çabaların sonucu yeni ticaret yolları ve bölgelerinin keşfedilmesi, kültürlerarası etkileşim, ekonomik büyüme, yeni ve rasyonel düşüncenin oluşmasında ve Avrupa devrimlere giden yolda önemli bir rol oynamıştır. Coğrafi Keşifleri, Ortaçağ’dan günümüze dünyanın büyük bir coğrafyasındaki toplumların ve devletlerin yaşadığı değişimlerin miladı olarak görebiliriz (Arnold, 1995: s.3). Bu milat Rönesans ve Reform Hareketleri ardından Fransız İhtilaliyle günümüze kadar gelen bir süreç başlatmıştır. 18. yüzyıldan itibaren Önce Avrupa'yı sonra tüm dünyayı etkileyen ulus, ulusçuluk, ulusal egemenlik, demokrasi, sekülerizm ve adalet gibi kavramlar toplumların değişimlerinde başat aktörler olmuştur. 19 . ve 20 . yüzyılda bu kavramların etkilediği toplumlar imparatorlukları yıkarak ulus devletlerini kurmuşlardır. Bazı toplumlar ise bağımsızlığını ve ulusal egemenliğini kurma sürecinde başarısız olmuş ve istikrarsızlığa sürüklenmiştir. Yaşanan bu iktidarsızlıkların bölgesel veya küresel etkileri olmuştur. Özellikle 20. Yüzyılın başından günümüzde kadar halen devam eden Ortadoğu Arap coğrafyasında ki toplumlarda yaşanan politik istikrarsızlık, etnik ve dini temelli çatışmalar bölgeyi ve dünyayı birçok yönden etkilemektedir.

\section{YÖNTEM}

Bu etkilerden hareketle makalede önce Fransız Devrimi’nin önemli bir öğesi olan ulus kavramının kökeni, zaman içerisinde geçirdiği evrimi ve devrimsel anlamı ortaya konulacaktır. Ortadoğu Müslüman toplumlarında anlamsal karşılığı olarak kullanılan millet veya ulus kavramının hangi değerler üzerinden hangi toplumları ifade ettiği analiz edilecektir. Millet ve ulus kavramının temsil ettiği sosyal yapıların ve özelliklerinin farkları ortaya konulacaktır. Osmanlı İmparatorluğu'ndan Müslüman bir toplumun olarak ulus devlete geçişte siyasi ve sosyolojik başarı sağlamış Türkiye Cumhuriyeti'nin ulus devlet olma süreci örneklendirilecektir. Ortadoğu Arap 
toplumlarında 20. Yüzyılın başından itibaren ortaya çıkan milliyetçi ve ulusalcı sosyalist siyasi hareketlerin Suriye'de ki ulus devlete geçiş denemeleri ve bu geçiş denemelerinin önemli aktörlerinden biri olan Mişel Eflak'ın siyasi hayatı, fikirleri, teorileri üzerinden etkilediği toplumlar ve siyasal rejimler ele alınacaktır. Sonuç olarak makalenin yazım amacı olarak sosyal inşacı yaklaşım üzerinden ulaşacağımız sonuçlar ışığında Eflak'ın fikirlerinin ve teorilerinin uygulamalardaki ki başarı veya başarısızlıkların nedenlerinin ve sonuçlarının ortaya çıkartılması hedeflenmiştir.

\section{AVRUPA'DA MILLETTEN ULUSA GEÇIŞ ÖRNEĞí}

Avrupa' da millet kavramı Latince "nación" kelimesinden gelen "nation” sözcüğü, İspanya Kraliyet Akademisi Sözlügünde 1884'ten önce bir ülkede bir krallıkta yaşayan insanların toplamı olarak anlamlandırılmıştır. Sözlügün 1884'de basılan sürümünde anlam değişikliğine uğrayarak modern öğeler içeren, sadakat odağı olarak merkezi bir ortak, egemen yönetimi kabul eden ve o devletin oluşturduğu topraklarda bir bütün olarak yaşayan insanlar ifade etmiştir. (Hobsbawm, 2006: ss.29-30). Latince 'den diğer batı dillerine geçen "nation” kavramı 18. Yüzyıla kadar doğum yerini belirten köken veya bu kökenle birbirlerine bağlı insan toplulukları için kullanılmıştır (Çanc1, 2008: ss.106-116). Millet ve milliyetçilik kavramı üzerinde birçok farklı yaklaşım ve görüşü barındıran bilimsel bir tartışma alanıdır. Millet ve milliyetçiliğin yapısı, ne zaman ve nasıl ortaya çıktığı konusunda genel olarak üç görüş hâkimdir. Bunlardan birisi milletlerin eski çağlardan günümüze var olduğunu öne süren ilkçilik yaklaşımı diğeri milletlerin modern dönemin bir ürünü olarak gören bunun yanında tarihi varlığını da göz ardı etmeyen etno-sembolculuk ve milletlerin sadece modern çağın bir ürünü olduğunu öne süren modernist yaklaşımdır (Altunoğlu, 2010: ss.1-7). Genel anlamda ilkçilere göre milletler insanlığın varlığından günümüze etnik, din, aile, dil gibi doğal oluşan bağlar kurarak tabii bir şekilde oluşmuş ve gelişmiştir. Etno-sembolcülerin eski ve modern çağları da içine alan yaklaşımı ise milletlerin tarihin her döneminde var olduğu görüşüdür. Etno-sembolcülerin ilkçilerden ayrıldı̆̆ı nokta ise milletlerin oluşumundaki tabiiliği reddederek inşa edilmiş sosyal yapılar olduğu ve milletlerin eski çağlardan modern dönemlere varlığının değişimlere uğrayarak günümüze kadar geldiğini öne sürmeleridir. Modernistler ise her iki yaklaşımı reddederek milletlerin modern çağların bir sosyal mühendislik ürünü olduğunu savunur ve 18. yüzyıldan sonra toplumlar tarafindan oluşan yeni şartlara göre inşa edilen bir proje olarak görmektedir (Akıncı, 2019: ss.413-430). Bu yaklaşımların ortak öğesi ise tarihin hangi döneminde hangi özelliklere sahip olursa olsun toplumun paylaştığı, niteliği değişkenlik gösterse de yüce sadakat odağıdır. YSO bir toplumda kolektif yaşamalarının şartlarını sağlayan ve kutsal sadakat ereğiyle oluşturulan en yüce kavram olarak milletlerin ya da ulusların merkezinde bulunan ve korunan birleştirici bir unsurdur (Oran, 2015: s.2). Avrupa'da Ortaçağ'da Rönesans ve reform hareketleriyle Avrupa'nın gelişen düşünce dünyası Fransız İhtilali'yle sonuçlanmış ve toplumların sadakat odağı olarak görülen din yerini ulus kavramına bırakmaya başlamıştır. Özellikle 20. yüzyılın başında 1. Dünya Savaşı'yla yıkılan imparatorlulardan ulusçuluğun inşa ettiği ulus merkezli sadakat odağına sahip birçok ulus devlet kurulmuş ve günümüz dünyasını şekillenmiştir. 


\section{TÜRKIYY'DE MILLETDEN ULUSA GEÇIŞ ÖRNEĞİ}

Türkçe'de de ulus ve millet kavramı etimolojik kökeni ve anlamı itibariyle ayrı kavramlardır. Türkçede millet; Arapça kökenli bir kelimedir. Eski Türk kaynaklarından Atebet-ül Hakayık adlı eserde millet kavramının anlamı aynı dine mensup topluluklar olarak geçmektedir (www.etimolojiturkce.com/kelime/millet, 2020). Şemseddin Sami'nin, Kamus-1 Türki adlı eserinde de millet kavramı dini bir toplulukları nitelemek için kullanılmıştır (Nişanyan, 2018). Günümüz tarihçilerinden İlber Ortaylı'nın İslam Ansiklopedisi'nde yazdığı millet maddesinde Osmanlı dönemindeki belgelerde millet kavramını Ermeni milleti, Papa'nın milleti gibi toplumları dinine göre ayırarak kullanmıştır (Ortaylı, 2005: ss.66-67). İslam kaynaklarında da millet aynı dine inanan kişilerin bir araya gelerek oluşturdukları cemaatin adı olarak geçmektedir (Şentürk, 2005: ss.64-66). Anadolu'da bağımsız bir Türk devleti kurulduktan sonra kurucu kadro tarafından Osmanlı İmparatorluğu'ndan kalan bakiyelerden biri olan millet kavramının ifade ettiği toplumsal yapı yerine Avrupa'daki örnekleri gibi bir ulus ve ulus devlet inşa etmek için siyasi ve sosyal alanda devrimler yapılmaya başlanmıştır. Yapılan bu devrimlerin temel öğelerinden birisi ise millet yapısından ulus yapısına geçerken bireylerin içinde bulunduğu yeni topluma bir bağ kurabilmesini sağlayacak yeni bir yüce bir sadakat odağının (YSO) inşa edilmesi olmuştur. Bu YSO Osmanlı Devleti'nde din iken yeni kurulan Türkiye Cumhuriyeti'nde yerini inşa edilen ulus kavramına olmuştur (Oran, 2015: ss.2-4). Yapılan devrimler meşruiyetini oluşturan hukuk devletinin bir gereği olarak yapılan anayasa ve kanunlardan almıştır. Bu anayasa ve kanunlar ulusal meclisin kurulmasıyla demokrasinin ve hukukun bir gereği olarak milletvekillerinin çoğunluk oylarıyla oluşturulmuş ve çıkartılmıştır. Teşkilatı Esasiye Kanununa hâkimiyetin kayıtsız ve şartsız milletin olduğu maddesi konulmuş, saltanat kaldırılmış, cumhuriyet ilan edilmiş ardından hilafet makamı kaldırılmış, tekke ve zaviyeler kapatılmış ve devletin dini İslam'dır hükmü kaldırılmıştır (Oran, 2015: ss.1011). Türkiye Cumhuriyeti'nin ulus devlet esaslarına göre düzenleyen ve devrimlerinin öncüsü olarak görülen $M$. Kemal Atatürk ise yeni değerler üzerine inşa edilen Türkiye'nin yeni yüce sadakat odağını:

"Devlet idaresinde bütün kanunlar, nizamlar, ilmin muasır medeniyete temin ettiği esas ve şekillere, dünya ihtiyaçlarına göre yapılır ve tatbik edilir. Din telakkisi vicdani olduğundan cumhuriyet, din fikirlerini devlet ve dünya işlerinden ve siyasetten ayr tutmayı milletimizin muasır terakkisinde başlıca muvaffakiyet görür”, sözüyle tarif etmiştir (Kurtcepe, 2015: ss.249-266).

Türk Ulus'unun ve devletinin inşası için yapılan devrimler topluma yeni bir kimlik vermiştir. Oluşturulan ulusal kimlik bir yönüyle de toplumu diğer toplumlardan ayıran özelliklerin özeti olarak görülebilir. Türkiye'de diğer Batılı örneklerinde olduğu gibi ulus ve ulus devleti inşa edilmesinin ana faktörü ise toplumlarda oluşan ulusçuluk duygusudur (Gelner, 1992: s.105).

\section{ORTADOĞU'DA MILLIYETÇILIK}

Fransız Devrimi'nin yarattığı ulusal bağımsızlık rüzgârı Ortadoğu'da da Osmanlı İmparatorluğu'nun egemenliği altında bulunan Arap toplumlarında hareketlenmelere sebep olmuştur. Daha önce Arap isyanları Osmanlı tarafından bastırılmışsa da 20. yüzyılın başında idarede, ekonomide zayıflamasının yarattığı otorite boşluğuyla, 
Ortadoğu'nun yer altı kaynaklarının keşfi ve Avrupa sanayisinin ihtiyaçları, bölgenin jeo-stratejik konumunun etkisiyle Avrupalıların da desteğiyle Arap İsyanları başlamıştır. 1. Dünya savaşı esnasında Arap dünyasında Osmanlı İmparatorluğu'na karşı bağımsızlık hareketleri doğmuştur. Bunların iki önemli örneği Şerif Hüseyin'in başını çektiği Haşim-i sülalesi ve Abdülaziz bin Suud'un önderliğinde Suud sülalesidir. Her ikisinin de isyan dayanağı bağımsızlık ereği ve dini iddialar olarak kaşımıza çıkmaktadır. Şerif Hüseyin Osmanlı'yı Arap coğrafyasını ve toplumlarını sömüren emperyalist bir devlet olarak ilan etmiştir. Kendisini Peygamber soyundan geldiği iddiasıyla Araplara kral olmanın doğal hakkı olduğunu öne sürmüştür. Abdülaziz bin Suud ise Şerif Hüseyin gibi Osmanlı'yı emperyalist ilan etmiş ve mensup olduğu Vehabi mezhebinin tekfirci itikadına göre Osmanlıların dinden çıktığını iddia etmiştir. Her ikisinin Oluşturdukları isyan hareketine ise İtilaf Devletleri destek vermiştir. Bu Arap ayaklanmalarının ortak özelliklerinden biri de kabilecilik sisteminin oluşturduğu milliyetçilik anlayışıdır. (Soy, 2014: s.177). I. Dünya Savaşı esnasında ise, İngilizler Çanakkale Savaşı'nın ve I. Kanal Seferi'nin lehlerine yarattığı ortamı kullanarak Abdülaziz bin Suud'u tarafsız kalmaya, Hicaz Emiri Şerif Hüseyin'i isyan etmeye yönlendirmiştir. İsyanları organize etmek için Arap Lawrence olarak tanınan meşhur İngiliz ajanı Thomas Edward Lawrence ${ }^{2}$ görevlendirilmiştir (https://ordaf.org/araplarbirinci-dunya-savasi, 2014).

Ortadoğu'da Arap isyancıların önderleri 1. Dünya Savaşı'nın atmosferinde bağımsızlık mücadelelerinin başarısını İtilaf Devletleri ile birlikte hareket etmekte görmüşlerdir. Fakat 1. Dünya Savaşı sonuçları isyancı Araplar için hayal ettikleri bağımsızlı̆̆ı getirmemiştir. Savaş esnasındaki müttefikleri olan İtilaf Devletlerinin Osmanlı'ya karşı Arap isyanlarını desteklemelerinin asıl nedenini Orta Doğu'yu paylaştıran Sykes-Picot Anlaşması ve Balfour Deklarasyonu'nda ortaya koymuşlardır. Yapılan anlaşmalara göre İngiltere ve Fransa yönetimleri bölgelerde kendi çizdikleri sınırların içerisinde krallıklar oluşturmuş ve sömürü siyasetine hizmet edebilecek yöneticileri başa getirmişlerdir. Irak’ta Mekke Emiri Şerif Hüseyin'in bir oğlu Faysal Irak krallığına getirilmiştir. Ürdün'de İngiltere'nin himayesinde Mekke Emiri Şerif Hüseyin'in diğer oğlu kral ilan edilmiştir. İngiltere yayınladığı deklarasyonla Yahudi Diasporasının Filistin'de bir devlet kurma hayalini desteklemiş ve günümüze kadar gelen bir Filistin sorununun temellerini atmıştır. Mısır'da ise Arap milliyetçiliğinin tam bağımsızlık mücadelesini kırmak için yarı bağımsız bir krallık kurulmasına izin vererek Kral 1. Fuad'1 (https://tasam.org/tr/Icerik/240/ortadoguda_dirilis_arap_milliyetciligi, 2006).

\section{ARAP SOSYALIZMİ ve BAAS PARTISİ}

Ortadoğu'da Fransa ve İngiltere tarafindan oluşturulan yarı teokratik monarşiler Osmanlı'dan bağımsızlık kazanmak isteyen Arap toplumlarını manda altında batı emperyalizmi ile karşı karşıya kalan daha zor bir duruma sokmuştur. Manda altında oluşturulan monarşi yönetimlerle karşı karşıya kalan Arap toplumlarında 1 Dünya Savaşı öncesi ve esnasında oluşmuş olan dine ve hanedana karşı olan sadakat odakları yerine Batı ve Türkiye örneğinde olduğu gibi sadakat odağı ulus olan devrimci

21916 - 1918 yılları arasında Arap Ayaklanması ve Sina ve Filistin Cephesi gibi olaylarda Osmanlı İmparatorluğu hâkimiyetine karşı üstlendiği rol ile ünlüdür. Buradaki rolü nedeniyle Arabistanlı Lawrence olarak tanınmıştır. 
düşünceler gelişmeye başlamıştır. Bu düşüncelerin toplumda en çok karşılık bulanı ise Arap sosyalizmi ve pan-Arapçı ideolojiler olmuştur. Bu düşüncelerin temeli Batı'da eğitim almış Rum Ortodoks Mişel Eflâk'ın öncülüğünde Sunni Müslüman Salâh Bitar ve Nusayri Zeki Arsuzi tarafından atılmıştır. Her üçü de Paris'te üniversite eğitimi alırken sosyalist düşüncelerle tanışmış ve sosyalizmin Arap toplumlarının kurtuluşu olacağına inanmışlardır (www.haberturk/yazarlar/murat-bardakci/641064-suriyerejiminin-fikir-babasi-miseli-olumunden-sonra-musluman-yaptilar, 2011).

Yurtdışında eğitimlerinin ardından ülkelerine dönen üç arkadaş kurdukları düşünce kulüpleri aracılığıyla toplumda fikirlerin yaymaya başlamışlardı. Bu süreç içerisinde etrafında düşünür kimliğiyle öne çıkan ve daha sonra Arap Sosyalizminin kuramcısı olarak anılacak Mişel Eflak lider olarak kabul görmeye başlamıştır. Mişel Eflak ve arkadaşları çalışmaları ile fikirleri kitlesel bir ideoloji haline dönüşmeye başlayınca siyasi olarak organize olmak ve fikirlerini siyasi zeminden iktidara taşımak için Fransız manda yönetiminden o dönem Suriye'de siyasi parti kurmak için zorunlu olan izin talebinde bulunmuşlardır. Osmanlı döneminde gücü elinde bulunan Suriye elitleri Fransız manda yönetiminde de işbirliği yaparak aynı güce sahip olmuşlardır. Bu elitler ekonomik ve siyasi gücü elinde tutan bir azınlık olarak Mişel Eflak ve arkadaşlarının paylaşımcı ve burjuva karşıtı sosyalist düşüncelerini ellerindeki ekonomik ve sosyal güce karşı doğal olarak tehdit görmüş ve karşı bir duruş sergilemişlerdir. Fransız manda yönetimi de devrimci ulusalcı sosyalist bir siyasi hareketin tehlikelerini göz önünde bulundurarak Eflak ve arkadaşlarına siyasi parti kurma izni vermemiştir. Eflak parti kurmak için gerekli izni alamayınca 1940 yılında Selahaddin Bitar ile birlikte Arap İhya Hareketini kurmuştur. Hareketin ismini 1942 yılında Arap Baas Hareketi olarak değiştirilmiş, 1947 yılında Zeki Arsuzi de Eflak ve Bitar ikilisine katılınca hareket partiye çevrilip, ilk kongrelerini yapmışlardır. Kongrenin nihayetinde Mişel Eflak partinin manevi lideri ve akıl hocası, Selahaddin Bitar ise genel sekreter olarak seçilmişlerdir. Hareketin ismi partileşerek Baas Partisi halini almıştır. (www.gzt.com/mecra/surije-rejiminin-fikir-babasi-misel-eflak, 2019) Böylece Suriye'de Arap ulusalcı, sosyalist, seküler ve anti-emperyalist öğelerle "Birlik, Özgürlük, Diriliş" sloganlarıyla tüm Arapları tek bir ulus olarak bir araya getirmeyi hedefleyen bir siyasi hareket başlamıştır.

\section{MIŞEL EFLAK'IN FÍKIR VE DÜŞÜNCELERİ}

Suriye'de Mişel Eflak'ın Batılı entelektüel düşüncelerinin sosyolojik etkilerini değerlendiğimizde; Suriye'de 1930'ların ortasına kadar hâkim olan bağımsızlık düşüncesi İslami öğeler içeren geleneksel olarak görebileceğimiz bir milliyetçilik anlayışıdır. Batılı sosyalist düşüncelerle toplumun sınıfsal yapısını ve ekonomiyi düzenlemek isteyen gruplar ve o döneme kadar bahsi geçen geleneksel milliyetçiler arasında 1930'ların ortasından itibaren çatışmalar başlamıştır.

2. Dünya Savaşı'nın getirdiği ortam sayesinde Fransız mandasının ortadan kalkmasıyla orta sınıflara hitap eden sosyalist fikirler ülke siyasetinde daha çok yer alma imkânı bulmuştur. Eğitimli Araplardan oluşan bu hareket eğitim için şehirlere gelen gençleri etrafında toplamıştır. Mişel Eflak'ın ve arkadaşlarının savunduğu toprak reformu, kırsalda yaşayan toprak sahibi olmayan ve genellikle etnik kimliği farklı olan işçilerinde Arap sosyalizmine desteğini sağlamıştır. Hareketin ulusalcı ve popülist 
siyasetine önemli katkıları olan Ekrem Havrani' de $^{3}$ askeri ve bürokratik çevresini ve Sünni köylüleri etkilemiştir (Özkoç, 2008: s.192).

Eflak fikirlerini geniş kitlelere duyurabilmek için Baas Partisi'nin kontrol ettiği Al-Baath adında bir gazete çıkartmıştır. Bu sayede geniş kitlelere ulaşmış ve iktidara muhalefet için gazetede verdiği demeç ve yazdığı yazılarla Arap dünyasında oldukça etki uyandırmıştır. Ayrıca Mişel Eflak partinin yayın organı Al-Baath gazetesinde Batılı değerlerle Arap değerlerini birleştirdiği Arap sosyalizmini ve pan-Arabist düşüncelerini toplumla paylaşmıştır. El-Baath gazetesinde çıkan röportaj ve yazılarında:

“Özgürlüğ̈̈ ve băğımsızlı̆̆ savunurken, gerçeklikle bağlantısı olmayan teorik bir şeye bă̆ll değiliz. Özgürlük, insanların günlük ekmeğinin nereye gittiğini ve servetlerinin, emek ve üretiminin meyvelerinin nasıl boşa harcandığını ve yöneticilerin nasıl resmi görevlerini yapmadı̆̆ını ve neden vicdanlarını bozduğunu bilmelerini sağlar. Ülkeyi neden ellerinde zorla tutuyorlar, herhangi bir ilerlemeyi özgürlüğ̈̈ önlüyorlar, ahlaki yozlaşmanın ve maddi iflasın devamını dayatıyorlar. Çünkü Özgürlük, insanların bağımsızlıklarını elde etmek için ulaştıkları yükseklikle onu tehdit eden dış tehlikeleri bă̆ımsızlı̆̆ın eksikliklerini bilmelerini mümkün kılar. Halk iktidarımızda Filistin davasını ve yabancı hegemonyanın nedenini, bilecekler. Ülkemizdeki yabancı şirketlerin nüfuz etmesinin, paramızı ve servetimizi yutmalarının, çalışanlarımıza karşı baskıların, bir şekilde bize karşı komplolarının farkında olacaklar," (Eflak, 1946: s.1).

Eflak, bu açıklamasıyla Suriye devlet yönetimini açık bir şekilde eleştirmiş yozlaşmanın ulaştığı seviyeyi emek, üretim kutsallığını vurgulayıp milli sermayenin sömürülmesine karşı anti-emperyalist bir tavır koyarak "özgürlük” kavramı üzerinde durmuştur:

"Ulusumuzun sorunu bizi gerçekten ve samimi bir şekilde endişelendiriyorsa cüretkâr olmalıyız. Cesur ve inatçı davranmazsak; halkı yanlış yönlendiren onları beyinlerini uyuşturarak insan sürüsü olarak gütmek isteyen eskimiş zihniyete bir son vermezsek ve bunu ani ve şiddetli bir şekilde yapmazsak maruz kalacağımız tehlike yabancı saldırı tehlikesidir çünkü kimliğinden ve özgürlüğünden yoksun olan insanlar topră̆ını savunamazlar. Birincisinden daha ciddi olabilecek diğer tehlike, böyle kalmanın ve herhangi bir sosyal inşanın veya toplumsal yaratıcılığın olamaması tehlikesidir," (Eflak, 1948: s. 1).

Eflak, bu açıklamasında sosyolojik tespitler yaparak mevcut iktidarı değiştirmenin zorunluluğunu ihtilalci bir dille ifade ederek toplumsal bir sosyal inşanın önemine vurgu yapmiştır:

"Arap vatanını özgürleştirmenin ve birleştirmenin tek yolu, halk kitlelerinin ülkenin yönetimine ulaşmasını ve işlerini devralmasını sağlamaktır. Tek başına kitleler, Arapların bağımsızlığını kazanma, topraklarının birleşmesi ve toplumlarının yeniden canlanmasına yönelik istek, ilgi, kabiliyet ve potansiyele sahiptir," (Eflak, 1956: s.1).

Eflak, bu açılamasında halkların devriminden ve bağımsızlık duygusundan Arap halklarının tek bir devlet altında birleşme istek ve potansiyelden bahsetmiştir:

3 Suriye'de yaygın bir popülist, milliyetçi hareketin oluşumunda ve Baas Partisi'nin yükselişinde önemli bir rol oynayan Suriyeli bir politikacıydı. 
“Íslam'ın bu tarihi ve önemli çağda ve kalkınmadaki bu belirleyici aşamada ortaya koyduğu anlam, tüm çabaların Arapları güçlendirmeye ve onları uyandırmaya yönelik olması ve bu çabaların Arap milliyetçiliği çerçevesinde olması gerektiğidir," (Eflak, 1943: s.1).

Eflak, bu açıklamasında İslam'ın Arapların bir değeri ve devrimi olduğunu ulusalcı sosyalist ve devrimsel özelliklerini önceleyerek ele almıştır.

\section{MISSEL EFLAK'IN SIYYASİ HAYATI}

İkinci Dünya Savaşı'nda Almanya'yla teslim anlaşmasını imzalayan Fransa Vichy Hükümeti'nin siyasetini yönlendiren Almanlar Suriye'yi ele geçirme çalışmalarındayken İngiliz ve Özgür Fransa kuvvetleri ortak askerî harekât düzenleyerek Suriye'de denetimi ele geçirmiş ve ülkenin bağımsızlığı ilan edilmiştir. Fakat yapılan seçimlerde 1943'te Fransa aleyhinde birleşen milliyetçi cephe hükümeti yapılan seçimleri kazanmış ve Şükrü el-Kuvvetli Suriye Devlet Başkanı seçilmiştir. Suriye’yi önce Sovyetler Birliği sonra ABD ve İngiltere bağımsız devlet olarak tanımış ve Fransa'nın da Suriye'nin bağımsızlığını tanıyarak ülkeyi terk etmesini istemişlerdir. Birleşmiş Milletler düzeyinde yapılan müzakereler sonrasında, İngiliz ve Fransız kuvvetleri, Suriye ve Lübnan'dan çekilmesi konusunda anlaşmışlardır. Fransa, 17 Nisan 1946'da Suriye topraklarından çekilmiştir. Böylece, Suriye'de 25 yıllık Fransız manda yönetimi sona ermiştir (Yazıc1, 2012: ss.349-403). Mişel Eflak ve arkadaşları 1946 yılına kadar Arap Baas hareketinin ideolojik alt yapısını ve entelektüel birikimini oluşturmuş bir kitle hareketine dönüşmüştür. Eflak ve arkadaşları 1946 yılında Fransız birliklerinin çekilmesi ve manda yönetiminin bitmesiyle iktidara gelmek için aktif bir şekilde siyasi çalışmalara başlamışlardır. 1947'de kurulan Baas Partisi'nin başına ilk kongrede seçilen Mişel Eflak fikirlerini hayata geçirmek için fursat bulmuş zor bir siyasi mücadeleye girmiştir https://www.britannica.com/topic/Bath-Party, 2020). 1948'de yaşanan Arap İsrail Savaşı'nda Arap koalisyonunun kaybetmesinden sonra Arap halkları mevcut yönetimleri sorumlu tutmuş, artan tepkiler Arap Sosyalizmi 'ne desteği daha da arttırmıştır. Bunun yanında Suriye'de 1949'dan 1963'e Baas Partisinin iktidarı ele geçirene kadar darbeler dönemi olarak adlandırılan bir dönem yaşanmaya başlamıştır. 1949 yılında bir Sünni General Hüznü Zaim, Suriye'nin bağımsızlıktan sonraki seçilen ilk Cumhurbaşkanı Şükrü El Kuvvetli 'ye karşı bir askeri darbe yapmıştır. Darbenin ardından kendisini Cumhurbaşkanı ilan ettirmiştir. Dört ay sonra ise General Sami Hınnavi karşı darbe yaparak Hüznü Zaim'i idam ettirmiştir. İngilizler Sami Hınnavi yönetimini ve Hınnavi'nin Irak ile Suriye'yi birleştirme fikrinin hayata geçirmesini desteklemiş bu şekilde de etkinliği olduğu Irak üzerinden Suriye'yi kontrolü altına almak istemiştir. Fakat 19 Aralık 1949'da Albay Edip Çiçekli, Irak ile birleşme siyasetinden dolayı, Sami Hinnavi'yi hainlikle suçlayıp darbe yapmıştır. Edip Çiçekli kendisini devlet başkanı ilan ettirmiştir. Edip Çiçekli döneminde Eflak, artan baskılardan dolayı Selahaddin Bitar'la birlikte Lübnan'a kaçmıştır. Lübnan'da Edip Çiçekli'nin iktidarına son vermek için bütün muhalif partilerle işbirliği yapma uğraşı vermiştir. 1953 yılında Ekrem Havrani'nin Arap Sosyalist Partisiyle birleşilerek Arap Sosyalist Baas Partisini kurmuşlardır. 1954 yılında Çiçekli’nin Albay Faysal El-Atasi tarafından devrilmesiyle Eflak ve Bitar Suriye'ye geri dönmüş ve akabinde yapılan seçimlerin sonuçlarına göre Millet ve Halk Partileri koalisyonu iktidar olmuştur. Baas 
Partisi ise mecliste 22 sandalye kazanarak muhalefette kalmıştır (https://www.gzt.com/mecra/surije-rejiminin-fikir-babasi-misel-eflak, 2019). Muhalefette kalan Baas Partisi ülkede iktidarı ele geçirmek için yeni kurulan hükümete karşı sokak protestoları organize ederek iktidardan çekilmelerini sağlamışlardır. Ayrıca protestolar ile genelkurmay başkanının istifa etmesinde önemli rol oynayarak ordunun içine de nüfuz etmişlerdir (Yazıcı, 2012: ss. 349-403).

Suriye'de Baas Partisi ordu içerisine nüfuz etmesiyle ve iktidarı organize ettiği protestolarla istifasını sağlamasıyla önemli bir güç kazanmıştır. Baas Partisi giderek Suriye'de ve bölge siyasetinde de güçlenmeye başlarken öte yandan Orta Doğu'da sosyalizmin gelişmesini önlemek amacıyla kurulan Bağdat Paktın'a Misır Devlet Başkanı Cemal Abdünnasır'ın karşı tavır almasıyla 1955'ten itibaren Mısır yönetimini desteklemeye başlamıştır. Mısır'da Abdünnasır ve Eflak arasında ilişkilerin gelişmesiyle 1956'dan sonra Bass Partisi Pan Arabist düşüncesinin bir yansıması olarak Suriye ve Misır'in birleşmesine yönelik siyaset yapmaya ve sokak gösterileri düzenlemeye başlamıştır. Öte yandan 1956 yılında yaşanan Süveyş Kanalı Krizi'nden sonrası İngiltere ve Fransa'nın Mısır'a saldırmaları Ortadoğu'da hem Batı aleyhtarlığını arttırmış hem de Pan Arabist ve antiemperyalist sosyalist fikirlere olan sempatiyi daha da arttırmıştır (Armaoğlu, 2017: s. 259).

\section{MISIR ve CEMAL ABDÜNNASIR}

Ortadoğu'da 20. yüzyıl siyasetinde önemli bir aktör olan 1918 doğumlu Cemal Abdünnasır milliyetçi duygularla 1930'lu yıllarda İngilizler 'in Mısır'1 terk etmesi için çalışan gruplara katılmıştır. Hukuk fakültesine kayıt olmasına rağmen ayrılarak harp okuluna gitmiş ve buradan mezun olmuştur. Askerlik hayatının ilk dönemlerinde Enver Sedat Zekerriya Muhyiddin ve Abdulhakim Amir gibi monarşi karşı1tı askerlerle ilişkilerini geliştirmiştir. İngiltere Mısır ile 1936' da yapılan anlaşmaya dayanarak bütün hava ve deniz limanlarını işgal etmesi Mısır'da milliyetçi hareketlerin ve antiemperyalist duyguların gelişmesinde önemli rol oynamıştır. Cemal Abdünnasır ve arkadaşları İngilizlerin ülke üzerindeki hâkimiyetine karşı mücadele için 1942'de Hür Subaylar hareketini kurmuştur (Kuzgun, 2015: ss.281-320). Hür Subaylar Hareketi Mısır'da 18 Temmuz 1953 tarihinde monarşi yönetimi devirmiş yerine cumhuriyet ilan ederek devlet başkanlığına General Muhammed Necib’i getirmiştir. Nasır ise başbakan yardımcısı ve içişleri bakanı olmuştur. Nasır Mısır'ın başına geçebilmek çoğunu bakan olarak atanmasını sağladığı ihtilal konseyi üyelerinin General Necib'i 1954 yılının mart ayında devlet başkanlığı görevlerinden uzaklaştırarak Mısır'da hâkimiyeti sağlayarak otokratik bir rejim oluşturmuştur (Duman, 2018: ss.102-114). Eflak ve Suriye Baasç1ları açısından Mısır'daki yaşanan bu değişim Pan-Arabizm siyasetinin önemli sıçrama noktası olarak görülmüştür. Mısır'ın tüm Arap dünyasını etkileyebilecek potansiyeli Ortadoğu'da diğer monarşilerin sarsılmasına ve Arap devrimini sağlayacak başat aktör olarak da öne çıkmıştır. Nitekim birleşik Arap ve sosyalist bir devlet kurmak için görüşmeler Nasır ve Eflak arasında başlamış ve kısa sürede olumlu sonuçlanmıştır.1

Şubat 1958'de Misır Suriye ve Kuzey Yemen'in katılımıyla Birleşik Arap Konfederasyon Cumhuriyeti (BAC) kurulduğu ilan edilmiştir. Fakat birleşmeden kısa süre sonra Mısır tarafından Suriye'nin iç işlerine müdahalesi ve Suriye kökenli yöneticiler yerine Mısırlı yöneticilerin getirilmesi Suriye tarafında ciddi rahatsızlıklar 
oluşturmuştur. Uygulanan sosyalist ekonomik politikalar Suriye toplumun orta sınıfını rahatsız etmiştir (www.21yyte.org/Nuriyev, 2012). Ayrıca Eflak'ın yol arkadaşlarına, Baas Partisi'nin yetkili kurullarına danışmadan ve ilgili kararlar alınmadan Nasır'ın birleşmenin bir koşulu olarak ortaya koyduğu şarta dayanarak partisini feshetmesi partisinde ayrılıklara yol açmıştır. Bunun yanında Abdünnasır'ın Birleşik Sosyalist Arap Devleti'nin kritik kadrolarına Misırlı yetkililer ataması Suriye Baas Partisi yönetimi tarafından tasfiye hareketi olarak algılanmıştır. Eflak, bu süreç içinde 1lımlı bir tavır sergilemesine karşın arkadaşlarının Suriye yönlü milliyetçi tavır almaları Eflak’ın siyasi konumuyla ilgili tartışmalara sebep olmuştur. Abdünnasır'ın Nasırcılık adını verdiği bir akım başlatması da nihai hedefte kolektif bir proje aktörü olmak yerine bireysel hedeflerinin olduğunu göstermiştir. Bazı partililer ve yöneticiler yaşanan bu krizden Eflak'1 sorumlu tutmuşlardır. 1958 yılında Suriye Baas Partisi faaliyetleri sonlandırıldığı hareketin devam edebilmesini sağlamak gerekçesiyle Salah Cedid ve Hafız Esad gibi Baasçı askerler askeri komiteler kurmuşlardır (Seale, 1990: ss.61-62). Ayrıca Suriye'de Nasır yanlıları da Birleşik Arap Cumhuriyeti'nin devam etmesi konusunda direnmişlerdir. Oluşan siyasi istikrarsızlık sebebiyle Abdülkerim el Nahlavi liderliğinde 27 Eylül 1961'de Suriye'de Birleşik Arap Devleti'nden ayrılmayla sonuçlanacak bir darbe yapılmıştır. İki yıl süren 1961 Darbesi Mişel Eflak’ın desteği ve onayıyla Baasçı askerler tarafından 1963 yılında 8 Mart Devrimi olarak adlandırılan karşı darbe yapılarak Baas Partisi Suriye'de iktidara gelmiştir. Fakat bu darbe veya devrim Suriye Baas Partisi'nin sivil bölümünden çok askeri bölümünün iktidarı olarak görülmüştür. Irak’ta ise 1958 yllında darbeyle monarşiyi bitiren Marksist düşüncelere sahip ve Baas fikrini benimsemeyen General Abdülkerim Kasım'a Suriye Baas darbesinden bir ay önce Irak'1n Baas kolu tarafından darbe yapılmıştır. Bu şekilde 1963 yılında Baas Partisi'nin askeri kolu hem Suriye'de hem Irak'ta iktidara gelmiştir. Ardından Suriye'de Baas Askeri Komitesi Eflak'ın öngördüğü 1lımlı sosyal ve ekonomik politikaları reddetmiştir. Komite, Eflak'ın yaşı ve yetersiz olduğuna inanarak, liderliği onun elinden almak için çalışmalara başlamıştır. 1965 yılında yapılan parti kongresini Eflak kaybetmiş ve yerine Munif Rezzaz ${ }^{4}$ seçilmiştir. Ardından Milli Komite yeni yönetimi belirlemiştir. Bu dönemde parti içindeki asker ve sivil çekişmeleri başlamıştır, asker kökenli Baasçılar sivil Baasçılara yakın olanların, sivil Baasçılar ise asker kökenli Baasçılara yakın olanların görevlerine son vermiştir. Asker sivil çekişmesi devam ederken 1966 yılında Hafız Esad ve Salah Cedid liderliğinde Baasçı subaylar yeniden darbe yaptığında partinin birçok sivil yöneticisi ülke dışına kaçmıştır. Eflak ve destekçileri gözaltına alınmış buna rağmen Eflak ordu içindeki bazı güvenilir arkadaşlarının yardımıyla önce Beyrut'a kaçmış, bir süre sonra Beyrut'tan Brezilya'ya gitmiştir. Suriye'de Hafız Esad ve Salah Cedid'in yaptığı darbeden sonra Baas Partisi Irak ve Suriye Baas Partileri adıyla ikiye ayrılmıştır. Eflak'ın düşüşünden sonra Suriye Baas Partisinin liderliğine Salah Cedid getirilmiş hareketin rehberinin Zeki Arsuzi olduğu kabul edilip, Eflak ve Bitar tamamen tasfiye edilmiştir. Eflak ve Bitar'dan sonra Salah Cedid ve Hafız Esad Suriye'nin yeni liderleri olmuşlardır. Ancak 6 Gün Savaşındaki yenilgi ve Kara Eylül Örgütü mensuplarının bazılarının Suriye’ye kabul edilmesi Salah Cedid ile Hafız Esad'ın arasının açılmasına neden olmuştur. 13 Kasım 1970 yılında Hafız Esad Salah Cedid'e karşı darbe yapıp liderlik koltuğuna oturmuş ve

4 Mişel Eflak'ın tasfiye edildiği Baas kongresinde yerine seçilen Ürdün asıllı Suriyeli politikacı. 
sonra ülkenin tek hâkimi olunca Eflak'ın gıyabında ölüm kararı vermiştir (https://www.gzt.com/mecra/surije-rejiminin-fikir-babasi-misel-eflak, 2019).

Bu karardan sonra Mişel Eflak Suriye üzerinde ki tüm etkisini kaybetmiştir. Fakat Irak Baas yönetimi Mişel Eflak'ı Irak'a davet etmiş vatandaşlık verip partinin başına geçirmişlerdir. Ürdün Kralı Hüseyin Filistinli gerillalara başlattığı askeri operasyona Irak'ın karşı bir tavır almayıp Filistinlilere destek vermemesine kızan Eflak 1970 yılında bu sefer Irak’1 terk edip Lübnan'a yerleşmiştir. 1974 yılına gelindiğinde Eflak Irak'a tekrar geri dönmüş ve tekrardan partinin başına getirilmiştir. Daha sonra 1979 yılında Saddam Hüseyin'in Irak'ın başına geçmesinde büyük rol oynamış fakat ölene kadar yönetimde bir söz hakkı olmamıştır. 1989 yılına kadar Irak’ta yaşamış ve Paris'te ölmüştür （www.haberturk.com/yazarlar/murat-bardakci/641064-suriye-rejiminin-fikirbabasi-miseli-olumunden-sonra-musluman-yaptilar, 2011). Ayrıca Mişel Eflak'ın resmi fikirleri dışında ailesiyle paylaştı̆̆ı iç dünyasını ve düşüncelerini yansıtan 1989 yılında ölümünden tam 28 yıl sonra 2017'de ortaya çıkan 29 Temmuz 1961'de karısına yazdı̆̆ mektubundan öğrenebiliriz:

"Kendi kendime sordum: ĕger uzun yaşamazsam onun durumu ne olacak? Bu, son dönemde çokça sorduğum bir soru. En yüce meslek olan tıp mesleğini benim yüzümden kaybettikten sonra sana ve çocuklarımıza kim bakacak, geçiminizi kim sağlayacak? Sen utangaç ve narin yapılı bir kız iken seninle kim ilgilenecek? Senin gözlerinin önünde birçok arkadaş ve yoldaşımın bana sırt çevirmelerinden dolayı bu iki senede maruz kaldı̆̆ım darbelere rağmen, insana olan güvenimi kaybetmedim. Aksine benim şuan insan tıynetinin iyi olduğuna olan inancım çok daha büyük... Bu yüzden sevdiğim ve sadık kaldı̆̆ım milletimin seni unutmayacă̆ına, Arapların vefa ve takdirlerini çokça göreceğine inanıyorum. Bunu kendimle övündüğ̈̈m için söylemiyorum, aksine üyesi olduğum milletin güzel bir şekilde takdir edeceğine güvendiğim için söylüyorum; bu millet biliyor ki ben ona bende olan her şeyi verdim. Bu süre zarfinda ve geçtiğimiz bu zor şartlarda hiç çekinmeden, halis sevgilerini bize gösteren ve cömertlik, yakınlık ve edeplerinde olabildiğince yüce mertebelere varan kişilerin az sayıda örneklerini benimle birlikte gördüğün halde, nasıl olur da insana güvenmeyelim ey sevgili?" (www.aawsat.com/mişel-efakın-eşine-yazdığı- "endişeli"- bir-mektubu-açığaçıkarmak/Khoury, 2017).

\section{SONUÇ}

Fransız Devrimi'nin getirdiği yeni kavramlar ve değerler üzerine inşa edilen ulusların ve devletlerin bazı toplumlara huzur ve refah getirirken bazı başarısız ulus devlete geçiş ve sosyal inşacılık denemeleri ise toplumlara siyasi istikrarsızlık ve çatışma getirdiği Orta Doğu Arap toplumları örneğiyle karşımıza çıkmaktadır. Avrupa'da gerçekleşen devrimler toplumdan yönetime doğru dikey bir şekilde Türkiye'de ise yönetimden topluma doğru düşey bir gerçekleşmiştir. Her iki millet kavramından ulus kavramına geçiş örneğinde toplumsal kültürel, siyasi, sosyolojik devrimlerle birlikte başarı sağlandığı görülmektedir. Ayrıca Türkiye örneğinden hareketle Müslüman bir toplum olmanın çağın batılı modern kavramları üzerinden bir ulus ve devlet inşa etmenin önünde engel olmadığı ortadadır. Orta Doğulu Müslüman Arap toplumlarının ulus devletlere geçiş denemelerinin başarısızlıklarının nedenleri bir yönüyle toplumsal sadakat odaklarının ulus devlet ve temsil ettiği değerler yerine dini 
ve aşiretçilik değerleri üzerine olmasıdır. Sosyolojik olarak Arap toplumlarında günümüzde halen devam eden güçlü aşiretçilik sistemi ve merkezi devlet ile aşiret yönetimi arasında otorite ve yetki devri sorunu ulus inşası önünde önemli bir engel olarak karşımıza çıkmaktadır. Kurulmuş ve halen günümüzde varlığını sürdüren Orta Doğu Arap devletlerinin çoğu ulus devlet yerine aşiretlerin oydaşmasıyla oluşmuş toplumsal yapılardır. Bu çeşit yapılar ise aşiretlerin devlet yönetimine paydaş olduğu yerlerde güçlü bir nepotizm oluşturmakta ve devlet yönetim sistemini işlemez hale getirmektedir. Diğer bir yönü ise Dini olarak Orta Doğu Arap toplumlarında mezhepsel ayrılıkların başta Şii ve Sünni olmak üzere kökleri İslamiyet'in ilk dönemlerine kadar uzanan anlaşmazlıkların var olması aynı etnik gruba sahip olan Arapların ortak bir siyasi otorite altında birleşmelerinde engel teşkil etmektedir. İslam'ın farklı yorumlamalarının oluşturduğu dini toplulukların birbirlerine yaşam hakkı tanımamaları bölgedeki istikrarsızlığın güçlü nedenlerinden biridir. İktisadi açıdan ise sanayi ve üretim toplumu haline gelememeleri öz kaynaklarını verimli bir şekilde işleyememelerine ve ekonomik dışa bağımlılığa sebep olmaktadır. Kurulan Baas yönetimleri aşiretlerin, dini grupların ve askeri darbeci yönetimlerin dışına çıkamamış ve bir ulus devlet inşa edememiştir. Mişel Eflak ve Baas yönetimlerinin millet ve ulus kavramının temsil ettiği değerler üzerinden ortaya koyduğumuz bilgiler 1şığında devrimlerini teoride ulus kavramı üzerinden pratikte ise millet kavramı üzerinden yapmaya çalıştıkları görülmektedir. Dolayısıyla yapılmak istenen devrimlerin ulus ve millet kavramlarının temsil ettiği değerler ve kavramlar arasında kalması ne devrimleri başarılı bir sonuca erdirebilmiş ne de geri dönüşe imkân vermiştir. Böylelikle günümüze kadar devam iktidarı ele geçirebilmek için etnik, dini ve aşiret gruplarının çekişmesi ve çatışması bölgesel istikrarsızlıklara sebep olmaktadır.

\section{KAYNAKÇA}

Khoury, A. (2017, Temmuz 7). Mişel Efak'ın eşine yazdı̆̆l "endişeli" bir mektubu açı̆̆a çıkarmak. Şarkul Avsat: 10.05.2020 Tarihinde : https://aawsat.com

Akad, M. (2002). Arap Milliyetçiliği: Baas Partisi . Popüler Tarih Dergisi, 42-62.

Akıncı, A. (2019). Milliyetçiliğin Kökenleri: Etnisite/Ulus (Millet) İlişkisi. İnsan ve Insan, 413-430.

Altunoğlu, M. (2010:). Millet İnşası Özcü Modernist ve Etno-Sembolcü Yaklaşımlar. Dumlupınar Üniversitesi Sosyal Bilimler Dergisi, 1-7.

Ankara Üniversitesi. (Erişim Tarihi: 11.05.2020). Ankara Üniversitesi Açık Ders Malzemeleri Milliyetçilik ve Azınlık. Ankara Üniversitesi Açık Ders: www.acikders.ankara.edu.tr

Antony, S. (1994). Milli Kimlik Çev: Bahadır, Sina, Şener. İstanbul: İletişim Yayınları.

Armanoğlu, F. (2017). 20. Yüzyll Siyasi Tarihi. İstanbul: Alkım Yayınevi.

Armanoğlu, F. (2017). Soğuk Savaş Dönemi 1945-1960. İstanbul: Alkım Yayınevi.

Arnold, D. (1995). The Age Of Discover,1400-1600, Çev: Osman Bahadır 1. Baskl. İstanbul: Mart Matbaacılık ve Sanatları. 
Bardakçı, M. (2011, Haziran 19). Suriye rejiminin fikir babası Mişel'i ölümünden sonra Müslüman yaptılar.17.05.2020 Tarihinde: www.haberturk.com/yazarlar

Çanc1, H. (2008). Değişmeyen Boyutları Bă̆lamında Milliyetçiliğe Teorik Ve Kavramsal Bir Bakış. Süleyman Demirel Üniversitesi İ̈BF Dergisi, 106-116.

Dinç, A. (2002, Haziran 01). Millet ve Milliyetçiliğin Doğuşu üzerine Kuramsal Yaklaşımlar. Sorgulama Zamanı Düşünce Topluluğu: http://www.sorgulamazamani.com/tr. Erişim Tarihi: 30.05.2020

Duman, T. İ. (2018). Müslüman Kardeşlerin Radikalleşme İhtimali: Abdunnasır Ve Sisi Dönemleri Karşılaştırması. Iv. Ortadoğu'da Siyaset Ve Toplum Kongresi (s. 102114). Sakarya: Sakarya Üniversitesi.

Durgun, F. (2014). Rönesans’tan 19. Yüzyıla Avrupa Tarih yazımında İlerleme Fikri, Dönemselleştirme ve Orta Çağ Avrupa Tarihi Algısı. Insan ve Toplum, 283-304.

Eflak, M. (1943, Nisan 1). Arap Peygamber Anısına. (Al-Bath, Röportaj Yapan)

Eflak, M. (1946, Ağustos 9). Neden Özgürlüğün Peşindeyiz. (A. B. Gazetesi, Röportaj Yapan)

Eflak, M. (1948, Şubat 27). Arap Toplumu. (A.-B. Gazetesi, Röportaj Yapan)

Eflak, M. (1956, Ocak 21). Yüzeysel ve Gerçek Varoluş Arasındaki Fark. (A.-B. Gazetesi, Röportaj Yapan)

Ernest, R. (2016). Ulus Nedir? Çev: Yavaş, Gökçe. İstanbul: Pinhan Yayıncılık.

Etimoloji, T. (2020, 05 08). Etimoloji Türkçe.12.05.2020 Tarihinde: www.etimolojiturkce.com

Gelner, E. (1992). Uluslar ve Ulusçuluk. Çev: Ersanlı Büşra. İstanbul: İnsan Yayınları.

Helden, A. (1995 ). The Inquisition. The Galileo Project: http://galileo.rice.edu/ Erişim: 20.05.2020.

Hobsbawm, E. Ç. (2006). Geleneğin İcadı. İstanbul: Agora Kitaplığı.

İktibas Dergisi. (2019, Nisan 22). Ulus Kavramı. İktibas Dergisi: www.iktibasdergisi.com

Kılıç, A. F. (2007). Din Sosyolojisinde Dini Grup Tipolojileri. Değerler Eğitimi Dergisi, $37-58$.

Kurşun, Z. (2014, Kasım 20). Araplar ve Birinci Dünya Savaşı. Ortadoğu ve Afrika Araştırmacıları Derneği: 28.05.2020 Tarihinde: www.ordaf.org.

Kurtçepe, İ. B. (2015). Türk İnkılabı, Atatürk'ün İlkeleri. Türkiye Cumhuriyeti Tarihi (s. 249-266). içinde Konya: Eğitim Yayınevi.

Kuzgun, M. (2015). Arap Birliğini Sağlama Sürecinde Bir Dönüm Noktast: Albay Cemal Abdülnasır Dönemi. Dünden Bugüne Uluslararası Orta Doğu Sempozyumu (s. 281-320). Elazığ: Fırat Üniversitesi Orta Doğu Araştırmalar Merkezi. 
Mahmut, Y. (2019, Ocak 29). Baas ideolojisinin fikir babası: Mişel Eflak. 15.05.2020 Tarihinde: www.gzt.com.

Nişanyan, S. (2018). Nişanyan Sözlük. Ş. Sami içinde, Kasmus_l Türki. İstanbul: Liber Plus Yayınları.

Nuriyev, E. (2012, Mayıs 29). Suriye Siyasi Tarihi. 21. yy Türkiye Enstitüsü: 15.05.2020 Tarhininde: www.21yyte.org .

Oran, B. (2015 ). Kemalizm İslamcılık Küreselleşme. Ankara SBF Dergisi, 54(2), 1-15.

Ortaylı, İ. (2005). Millet Maddesi. T. Diyanet Vakfi içinde, İslam Ansiklopedisi (s.6670). İstanbul: Diyanet Vakfi.

Özkoç, Ö. (2008). Suriye Baas Partisi:Kökenleri, Dönüşümü,İzlediği İç Ve Dlş Politika(1943-1991). Ankara: Mülkiyeliler Birliği Yayınları.

Seale, P. (1990). Asad: The Struggle for the Middle East. Kaliforniya: University of California Yayınları.

Soy, H. B. (2014). Arap Milliyetçiliği: Ortaya Çıkışından 1918'e Kadar. Bilig, 177.

Şentürk, R. (2005). Millet Kavramının İslam'da Anlamı. İslam Ansiklopedisi. İstanbul: Türkiye Diyanet Vakfı Yayınları İslam Ansiklopedisi, 64-65.

Türkiye Asya Stratejik Araştırmalar Merkezi. (2006, Aralık 14). Orta Doğu'da Diriliş Arap Milliyetçiliği. Tasam: 15.05.2020 Tarihinde: www.tasam.org

Vefik, A. (2000). Lugat-ı Osmani 15.05.2020 Tarihinde www.tdk.gov.tr

Yaşar, M. (2019, Ocak 01). Baas İdeolojisinin Fikir Babası Mişel Eflak. 15.05.2020 Tarihinde https://www.gzt.com/mecra/surije-rejiminin-fikir-babasi-misel-eflak.

Yazıc1, N. (2012). "Suriye Siyasi Tarihi”. Ü. Özdağ içinde, Küçük Orta Doğu Suriye. Haz. Ü. Özdă̆, Ankara: Kripto Yayınları, 349-403.

Yükneki, E. A. (2020). Millet Kelime Kökeni, Atabet-ül Hakayık. Etimoloji Türkçe: 10 Mayıs 2020 tarihinde www.etimolojiturkçe.com.

Zeidan, A. (2020, Nisan 30). Ba'ath Party. britannica Ansiklopedisi 15.05.2020

Tarihinde :Web sitesi: www.britannica.com. 